研 究

\title{
磁性粉末の球形化による圧粉磁心の直流重畳特性への影響とモデル化
}

\author{
繁田 進, 大島 泰雄, 赤岩 功太 \\ 琍夕ムラ製作所，广350-0214 坂戸市千代田 5-5-30.
}

\section{Effects of Powder Sphericalization on DC Biased Properties of Powder Cores and Modeling}

\author{
Susumu Handa, Yasuo Oshima and Kouta Akaiwa \\ Tamura Corporation, 5-5-30 Chiyoda, Sakado 350-0214, Japan.
}

Received February 1, 2010

\begin{abstract}
SYNOPSIS
Effects of powder sphericalization on DC biased properties of powder cores have been investigated and simulated using a nonmagnetic grain boundary (NMGB) model. Water atomized iron powder and Fe- 6.5 mass \% Si powder have been sphericalized by a powder surface modification system. Aspect ratio has got smaller depending on rotational speed. Aspect ratio of the former at rotational speed $8000 \mathrm{rpm}$ and $180 \mathrm{sec}$ have gotten as 1.29 equivalent to gas atomized iron powder and DC biased property has been improved. They have been compared with values calculated by the NMGB model. The relative inaccuracy has been within $4.23 \%$. Aspect ratio of the latter (Fe-6.5 mass \% Si powder) has had smaller with higher rotational speed, while DC biased property has not been improved. They have been compared with values calculated by the NMGB model. The relative inaccuracy has been within $4.68 \%$. The gap width distribution has been compared between calculated and measured values. The relative inaccuracy of the average gap width has been $5.17 \%$ on the iron powder core and $78.3 \%$ on the $\mathrm{Fe}-6.5$ mass $\% \mathrm{Si}$ powder core.
\end{abstract}

KEY WORDS

powder core, magnetic property, DC biased property, permeability, aspect ratio

\section{1 緒 言}

近年, 地球温暖化防止のため, グリーン家電や電気自動車 および再生可能エネルギー製品として太陽光発電システム等 が注目されている.これらの機器に用いられるリアクトルは, 駆動周波数が $20 \mathrm{kHz}$ までの用途において, 磁心として電磁鋼 板が用いられている ${ }^{1)}$.これらの用途においては，大電流に おいても磁気飽和しないことが重要であり, 磁路の一部に工 アーギャップを設けている、このため, ギャップ部近傍にお ける漏れ磁束のために損失が増大する.

圧粉磁心は電磁鋼板を用いた磁心と比較し, 形状が自由で あること・磁気的に等方性であること・高周波数においても 損失が小さいこと等により，これらの用途にも用いられるよ うになってきた2)。また，圧粉磁心は粉末に絶縁被膜を作製 し成形・焼鈍を行なうため, 粉末間にギャップが存在し, そ れが磁心としての分散ギャップの効果を果たしている.この ため, その粒子間ギャップを制御することにより, エアー
ギャップを無くすことやその幅を小さくすることができ, 漏 れ磁束の低減により損失の低減がはかれる。しかしながら, 圧粉磁心は電磁鋼板を用いた磁心と比較して, 磁心のバルク 体と比較した相対密度の低下による飽和磁化の低下や, ギャップの不均一性等による直流重畳特性の低下等があり, 省電力化から低損失, 小型・低コス卜化から高直流重畳特性 が要望されている.

圧粉磁心の直流重畳特性は, 粉末固有の透磁率や飽和磁化, 磁心のバルク体と比較した相対密度に依存する磁心としての 飽和磁化, 磁心を構成する粉末間のギャップ幅の大きさと分 布等に依存する. ギャップ幅は粒子形状や粒子径分布, バイ ンダー等の粒子間介在物, 成形条件による磁心のバルク体と 比較した相対密度等に依存する. これらの物理的因子と直流 重畳特性の関係を明確にすることにより, 磁心設計の指針を 得ることができる。この結果, 磁心の特性改善や開発の時間 短縮等が容易になる. 
これまでに, $\mathrm{Fe}-9.5$ mass \% Si-5.5 mass\% Al 粉末を用いた圧 粉磁心に対し, 粉末の作製方法を調整してアスペクト比を変 えた試料を作製し，アスペクト比が直流重畳特性に及ぼす影 響を検討している ${ }^{3)}$.この直流重畳特性にたいして，指数関 数近似尔をもちいたモデルから計算した結果と比較し誤差 $1 \%$ 以内での一致を得た。しかし，指数関数式で用いている定数 $\mathrm{k}_{1}, \mathrm{k}_{2}, \mathrm{k}_{3}$ の物理的な意味が明確ではない。また，Fe-3 mass\% $\mathrm{Si}$ 粉末による圧粉磁心に対し, 個々の粉末粒子はその形状や 粒径に分布を有すること, 粒子間ギャップ幅に分布を有する ことを考慮して，反磁界に分布をもたせて初磁化曲線を検討 している5). しかしながら，これらの方法では物理的因子と 直流重畳特性の相関が明確ではない.このような問題を解決 する方法として，微結晶粉末を用いた圧粉磁心に対し，非磁 性結晶粒界(Non Magnetic Grain Boundary: NMGB) モデル ${ }^{6)}$ 直流重畺特性に適用した研究がある7)。この研究では, 印加 磁界は反磁界と等しいとする近似を用いており，低磁界にお いて誤差が大きい。この誤差の原因として，近似方法・粒度 分布として用いた個数基準による粒度分布が考えられる.

本研究では，NMGBモデルをもとに，印加磁界は反磁界と 等しいとする近似を用いずに直流重畳特性を求めるモデルを 検討した．純鉄粉と Fe-6.5 mass\% Si 粉について，水アトマイ ズ粉に対し球形化処理を行なうことによる直流重畳特性への 影響を評価した。 また，各組成におけるガスアトマイズ粉末 についても評価した。これらの試料について，粒子間の ギャップ幅に分布をもたせたNMGBモデルを適用して直流重 畳特性值を計算し実測値と比較した．さらに，本モデルによ り計算されたギャップ幅分布について, SEM写真による実測 值との比較を行ない，モデルの妥当性を検討した.

\section{2 試料および実験方法}

粉末は, 純鉄粉末と Fe-6.5 mass\% Si粉末を用いた。一般に, 粒度分布は対数正規分布で近似できる. 実測值の累積粒度分布 から,最小二乗法により質量での幾何平均径 $\mathrm{D}_{\mathrm{gave}}\left(=\exp \left(\mathrm{D}_{\mathrm{ave}}\right)\right)$ と幾何標準偏差 $\sigma_{\mathrm{g}}\left(=\exp \left(\sigma_{\mathrm{x}}\right)\right)$ を求めた. ここで $\mathrm{D}_{\mathrm{ave}}, \sigma_{\mathrm{x}}$ は粒 子径 $\ln \mathrm{D}$ の平均值, $\ln \mathrm{D}$ の標準偏差であり $\mathrm{D}_{\mathrm{ave}}$ はサンプル数を 規格化するとメジアン径 $\mathrm{D}_{50}$ となる，前者は, 粒径 $150 \mu \mathrm{m}$ 以 下で幾何平均径 $\mathrm{D}_{\mathrm{gave}}=84.6 \mu \mathrm{m}$ (幾何標準偏差 $\sigma_{\mathrm{g}}=1.49 \mu \mathrm{m}$ ) の 水アトマイズ粉と, 比較のため粒径 $150 \mu \mathrm{m}$ 以下で幾何平均径 $\mathrm{D}_{\mathrm{gave}}=57.8 \mu \mathrm{m}$ (幾何標準偏差 $\sigma_{\mathrm{g}}=1.62 \mu \mathrm{m}$ ) のガスアトマイズ 粉を用いた. 後者は, 粒径 $75 \mu \mathrm{m}$ 以下で幾何平均径 $\mathrm{D}_{\mathrm{gave}}=48.6 \mu \mathrm{m}$ (幾何標準偏差 $\sigma_{\mathrm{g}}=1.55 \mu \mathrm{m}$ ) の水アトマイズ粉と, 粒径 $75 \mu \mathrm{m}$ 以下で幾何平均径 $\mathrm{D}_{\mathrm{gave}}=38.3 \mu \mathrm{m}$ (幾何標準偏差 $\sigma_{\mathrm{g}}=1.52 \mu \mathrm{m}$ ) のガスアトマイズ粉を用いた. 各水アトマイズ粉末に対して 表面改質装置であるハイブリダイザー: NHS-1型(侏奈良機械 製作所)により球形化処理をおこなった．処理量を $120 \mathrm{~g}$ ，処 理時間を 3 min に固定した. Fig.1, Fig.2 は純鉄粉末と Fe-6.5 mass\%Si 粉末を用いた場合について，回転数を $4800(\mathrm{~b}, \mathrm{~g})$, $6400(\mathrm{c}, \mathrm{h}), 8000(\mathrm{~d}, \mathrm{I}) \mathrm{rpm}$ とした粉末の SEM 写真を示す. $(a, f)$ は処理なし, (e,j) は処理無しのガスアトマイズ粉末の SEM写真である. これらの粉末に対し, 粉末単独の熱処理に おける融着防止のためシランカップリング剤による表面コー ティングを行い, 還元雾囲気中で温度 $1127 \sim 1173 \mathrm{~K}$, 保持時 間 $7.2 \mathrm{ks}$ の熱処理をおこなった。この粉末にシランカップリ ング剤とシリコーン樹脂を添加し造粒機により造粒をおこな い, 乾燥後目開き $500 \mu \mathrm{m}$ の節により解砕した.さらに, 潤滑 材を 0.35 mass \% 添加し成形用粉末とした。成形は, 1 軸の油 圧プレス機によるフローティングダイ法で，成形圧力970〜

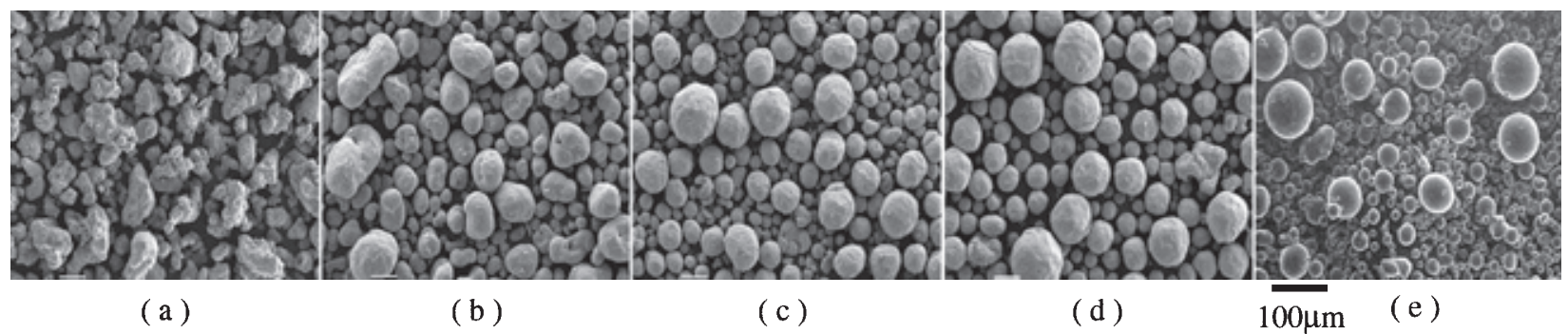

Fig.1 SEM photographs of water atomized (a), sphericalized powder (b, c, d) and gas atomized (e) iron powder.

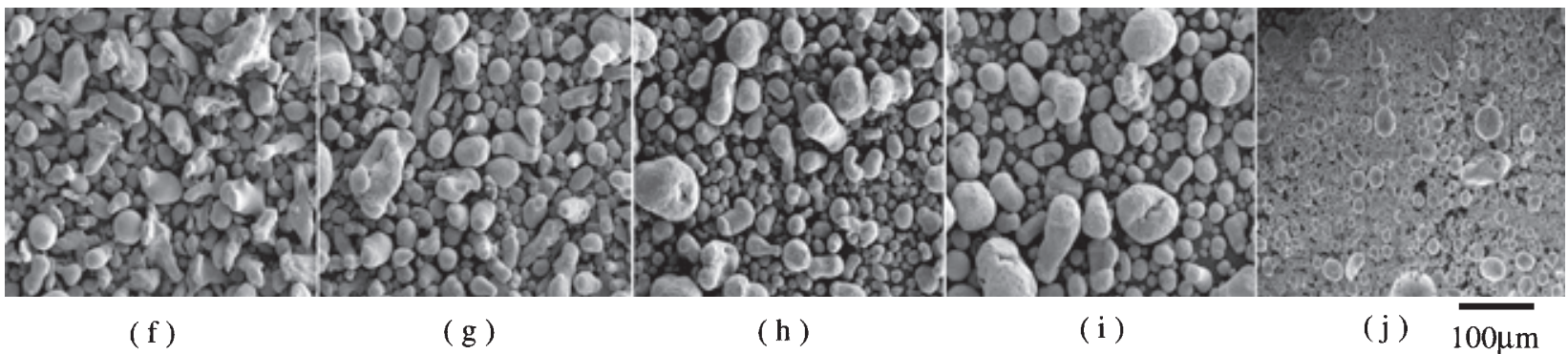

Fig.2 SEM photograph of water atomized (f), sphericalized powder (g, h, i) and gas atomized (j) Fe- 6.5 mass \% Si powder. 
$1950 \mathrm{MPa}$ でおこない, 外形 $16 \mathrm{~mm}$, 内径 $8 \mathrm{~mm}$, 高さ $5 \mathrm{~mm}$ の トロイダル磁心を作製した。この成形体を還元雾囲気中で温 度 $673 \sim 973 \mathrm{~K}$ ，保持時間 $1.8 \sim 7.2 \mathrm{ks}$ で熱処理 (焼鈍) をおこ なった.この磁心に 1 次, 2 次巻線を施し磁気特性を測定し た. Table 1 は球形化処理条件と圧粉磁心の作製条件をまとめ たものである。

表面観察は SEM (日本電子製 : JMS-6390LA)，レーザー顕 微鏡 (オリンパス社製 : LEXT OLS3500)を用いた。磁心の直 流磁化特性は B-H アナライザー(電子磁気工業製 : BH-5501) により測定した.

\section{3 実験結果および考察}

3.1 表面形状と磁気特性

Fig.3,4は焼鈍を行なった圧粉磁心を樹脂に埋め込み, 成形 面と垂直方向の面を鏡面研磨をおこない観察したレーザー顕 微鏡写真である. (a) から (j) の試料は Fig.1, 2 と同一である. Fig.3は純鉄粉, Fig.4はFe-6.5 mass Si 粉末を用いた結果であ る. 黒い部分は研磨中に粉末が脱落した箇所であり, ギャッ プ幅測定のデータからは除外した. Fig.3 (a)で顕著な様に, 成 形方向に対し垂直方向の長楕円形状になっていることがわか る. Fig.3, 4 において縦 $280 \times$ 横 $330 \mu \mathrm{m}^{2}$ の範囲における全粒

Table 1 Process conditions of the samples.

\begin{tabular}{|c|c|c|c|c|c|c|c|c|c|c|}
\hline \multirow{3}{*}{ Sample } & \multicolumn{2}{|c|}{ Powder } & \multicolumn{2}{|c|}{ Sphericalization } & \multicolumn{2}{|c|}{ P. heat tr. } & \multirow{2}{*}{ Pressure } & \multirow{2}{*}{$\begin{array}{c}\text { Green } \\
\text { density }\end{array}$} & \multicolumn{2}{|c|}{ Anneal } \\
\hline & \multirow{2}{*}{$\begin{array}{c}\text { Compos } \\
\text { ition }\end{array}$} & \multirow{2}{*}{ Method } & Yes & Rotation & Temp & Time & & & Temp & Time \\
\hline & & & No & rpm & $\mathrm{K}$ & $\mathrm{ks}$ & GPa & $\mathrm{Mg} / \mathrm{m}^{3}$ & $\mathrm{~K}$ & $\mathrm{ks}$ \\
\hline $\mathrm{a}$ & \multirow{5}{*}{$100 \% \mathrm{Fe}$} & \multirow{4}{*}{ Water } & \multicolumn{2}{|r|}{$\mathrm{N}$} & \multirow{4}{*}{1173} & \multirow{5}{*}{7.2} & \multirow{5}{*}{0.97} & 7.27 & \multirow{4}{*}{773} & \multirow{4}{*}{7.2} \\
\hline $\mathrm{b}$ & & & \multirow{3}{*}{ Y } & 4800 & & & & 7.07 & & \\
\hline $\mathrm{c}$ & & & & 6400 & & & & 7.38 & & \\
\hline $\mathrm{d}$ & & & & 8000 & & & & 7.42 & & \\
\hline $\mathrm{e}$ & & Gas & & $\mathrm{N}$ & 1123 & & & 7.43 & 873 & 1.8 \\
\hline$f$ & \multirow{5}{*}{$\begin{array}{c}\mathrm{Fe}- \\
6.5 \% \mathrm{Si}\end{array}$} & \multirow{4}{*}{ Water } & \multicolumn{2}{|r|}{$\mathrm{N}$} & - & - & \multirow{2}{*}{1.95} & 6.89 & \multirow{2}{*}{673} & \multirow{2}{*}{1.8} \\
\hline $\mathrm{g}$ & & & \multirow{3}{*}{ Y } & 4800 & 1173 & 7.2 & & 6.74 & & \\
\hline $\mathrm{h}$ & & & & 6400 & & & \multirow{2}{*}{-} & 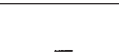 & \multirow{2}{*}{-} & \multirow{2}{*}{-} \\
\hline $\mathrm{i}$ & & & & 8000 & & & & - & & \\
\hline $\mathrm{j}$ & & Gas & & $\mathrm{N}$ & - & - & 1.49 & 6.67 & 973 & 7.2 \\
\hline
\end{tabular}

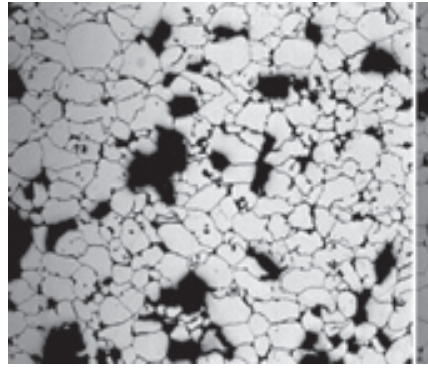

(a)

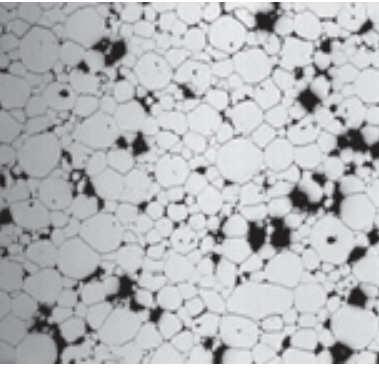

(c)

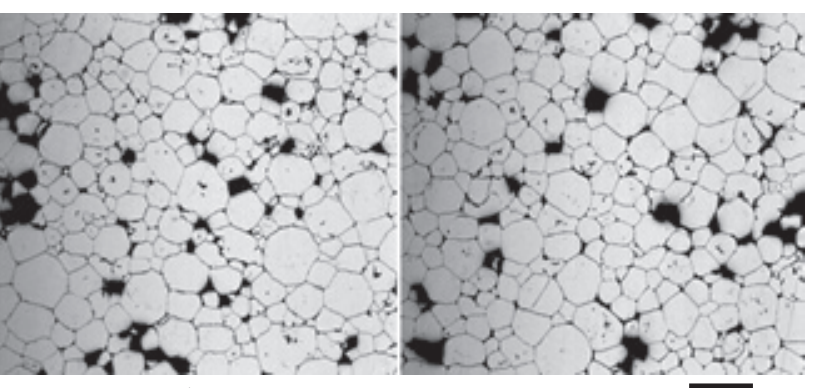

(d) (e) $10 \overline{\mu \mathrm{m}}$

Fig.3 Cross sectional SEM photographs of the cores made of iron powder (a, b, c, d, e).

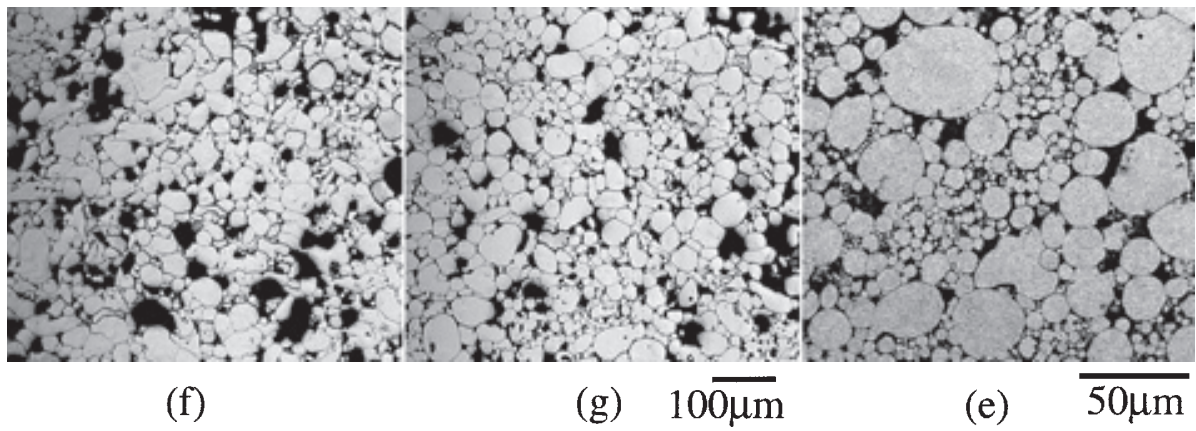

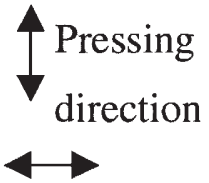

Magnetic field

Fig.4 Cross sectional SEM photographs of the cores made of Fe-6.5 mass \% Si powder (f, g, e). 
子について, 長径と短径を測定してアスペクト比を計算した. Fig.5は, 各粉末についての表面改質装置の回転数とアスペク ト比の関係を示す. 回転数が大きくなるほどアスペクト比が 低下する，すなわち球形に近づいている. 純鉄粉の場合，回

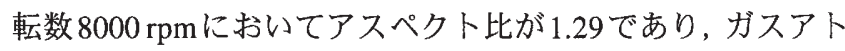
マイズ粉末では 1.32 となる.

これらの磁心に 1 次巻線 180 ターン, 2 次巻線 10 ターンを 巻き回し, 最大磁界 $10 \mathrm{kA} / \mathrm{m}$ として直流初磁化曲線を測定し

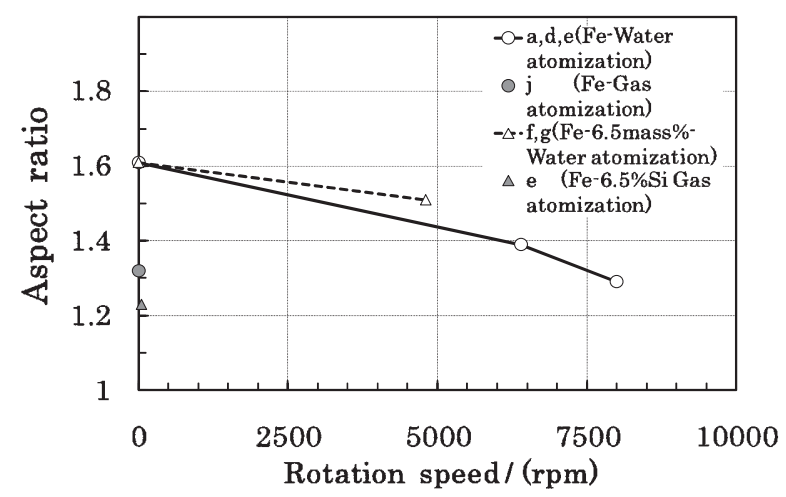

Fig.5 Aspect ratio with rotation speed of a powder modification machine.

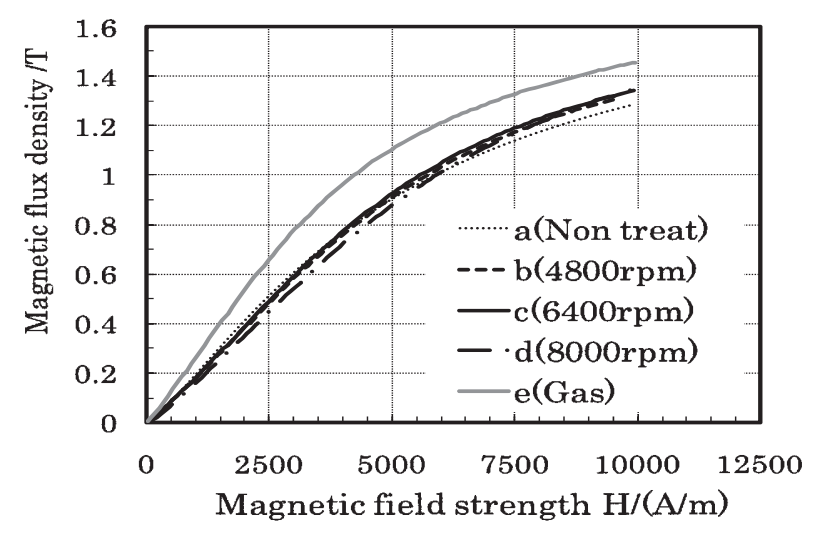

Fig.6 Initial DC B-H loops of the cores made of iron powder $(a, b, c, d, e)$.

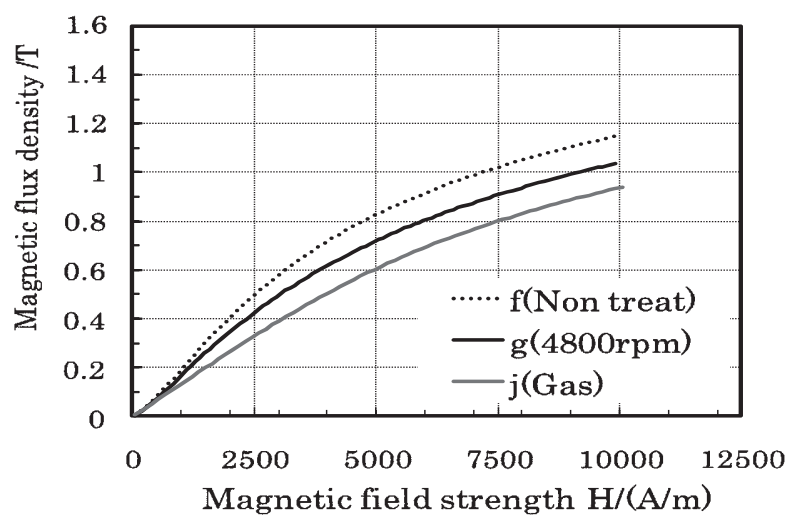

Fig.7 Initial DC B-H loops of the cores made of Fe-6.5 mass \% Si powder (f, g, j).
た. Fig.6,7は純鉄粉および Fe- 6.5 mass \% Si 粉末を用いた圧粉 磁心の直流初磁化曲線である. Fig.8,9はその曲線から磁界幅 を約 $150 \mathrm{~A} / \mathrm{m}$ にして微分透磁率を計算した直流重畳特性を示 す.

純鉄粉においては, 球形化処理の回転数を上げるほど磁界 $1 \mathrm{kA} / \mathrm{m} \sim 2 \mathrm{kA} / \mathrm{m}$ の範囲において微分透磁率が一定となる領域 が広がり，その値も小さくなることがわかる．ただし，回転 数 4800 と $6400 \mathrm{rpm}$ では大きな違いはない．微分透磁率が小 さくなる原因は，成形密度とアスペクト比が考えられる，成 形密度に関しては, 回転数 4800 と $6400 \mathrm{rpm}$ の成形密度が 7.07 々 $7.38 \mathrm{Mg} / \mathrm{m}^{3}$ 之違うのにも倸わらず微分透磁率に大きな違い はない.この結果, 成形密度の影響よりもFig.5からわかるよ うにアスペクト比が小さくなり反磁界係数が大きくなること による影響が大きいと考えられる. Fe-6.5 mass\% Si 粉末にお いては, 純鉄粉と同様球形化処理により磁界 $1 \mathrm{kA} / \mathrm{m}$ 近傍にお ける最大の微分透磁率が小さくなる.

3.2 NMGB モデルによる直流重睴特性の理論式()

圧粉磁心を構成する粉末は, 高さ $\mathrm{e}$, 幅 $\mathrm{D}$, 奥行き $\mathrm{e}$ の直方 体であるとし, 各粉末は, 粒子間にギャップ $\delta$ を有しており, 体心立方構造で配置していると仮定する，ただし，Dと e は

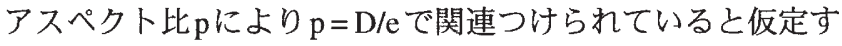

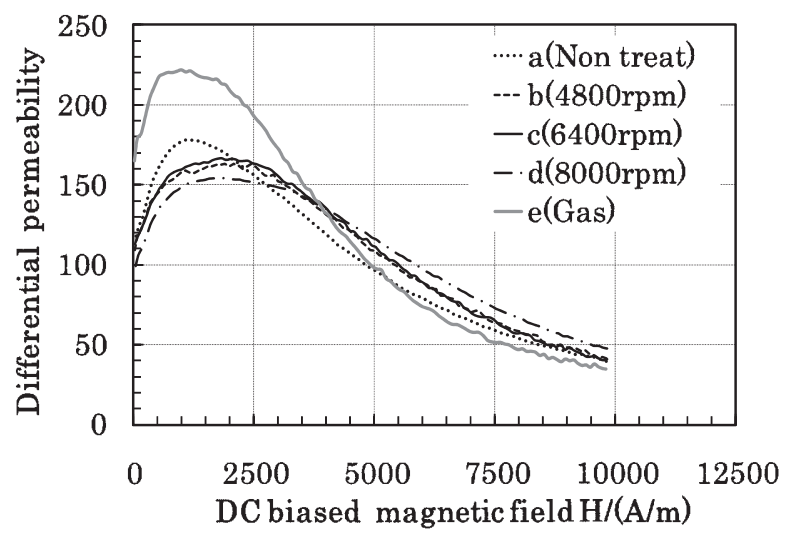

Fig.8 DC biased magnetic property of the cores made of iron powder (a, b, c, d,e).

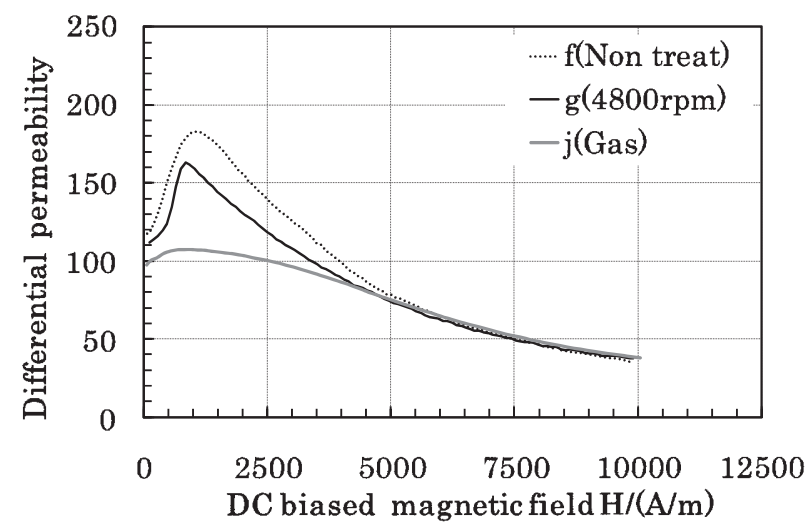

Fig.9 DC biased magnetic property of the cores made of Fe-6.5 mass \% Si powder (f, $g, j)$. 
る. Fig.10はこのモデルを $\mathrm{x}-\mathrm{y}$ 平面で示す, Fig.11 は x-z 平面 と等価回路で示す. Fig.11からわかるように, 体心立方構造 配置の場合, 単位セルにおいて上下 4 個づつ計 8 個の粒子と 接している. Fig.12は, 磁束が上下 8 個の粒子も貫くとした 場合の等価回路を示す.

3.2.1 粒子径が一定の場合

先ず, 粒子径が一定の場合における単位セルの比透磁率 $\mu_{\mathrm{ue}}$ $(\delta, \mathrm{p}, \mathrm{D})$ を求める. 単位セルは断面積が $(\mathrm{e}+2 \times \delta / 2)^{2}$ で磁路長 が $(\mathrm{e}+2 \times \delta / 2)$ であるから, 比透磁率 $\mu_{\mathrm{ue}}(\delta, \mathrm{e}, \mathrm{D})$ は次式で表 せる。

$$
\mu_{\mathrm{ue}}(\delta, \mathrm{e}, \mathrm{D})=\frac{\mathrm{D}+\delta}{(\mathrm{e}+\delta)^{2}} \times \frac{1}{\mu_{0}\left(\Re_{\mathrm{p}}+\Re_{\mathrm{gx}} \| \Re_{\mathrm{gz}}\right)}
$$

ここで, $\mu_{0}$ は真空の透磁率であり, $\Re_{\mathrm{p}}$ は粒子の磁気抵抗，

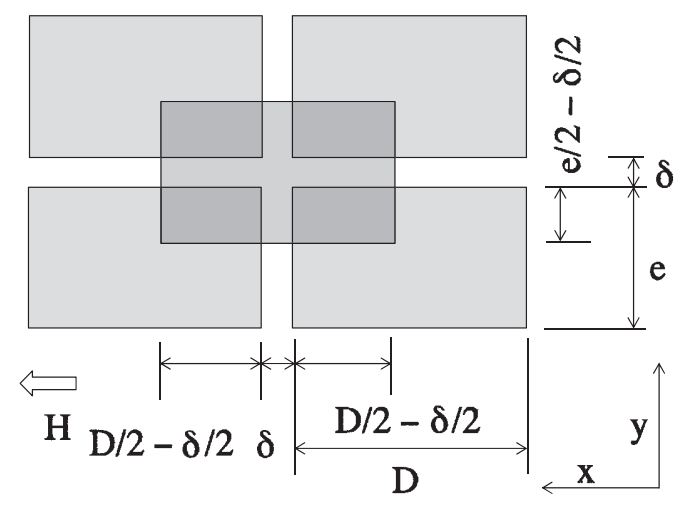

Fig.10 Unit cell sketch of body-centered rectangular packing in $x-y$ plane.

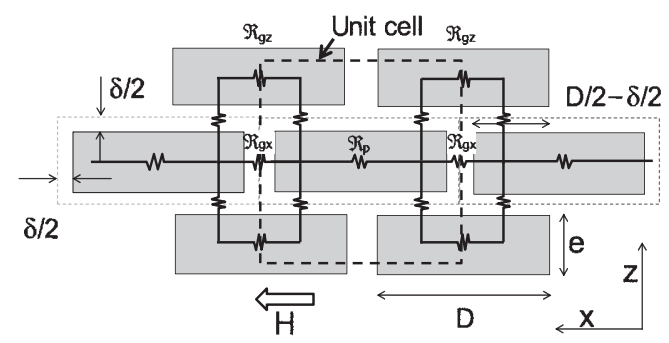

Fig.11 Unit cell sketch of body-centered rectangular packing in $\mathrm{x}-\mathrm{Z}$ plane and equivalent circuit.

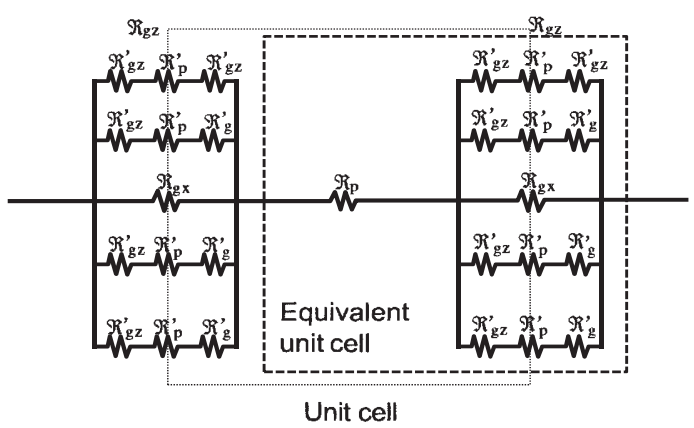

Fig.12 Equivalent circuit of the unit cell.
$\Re_{\mathrm{gx}} \| \Re_{\mathrm{gz}}$ はx, z 方向が並列回路とした場合の磁気抵抗である. これらはx, z 方向のギャップの磁気抵抗 $\Re_{\mathrm{gx}}, \Re_{\mathrm{gz}}$ を用い次式 で表せる.

$$
\begin{aligned}
& \Re_{\mathrm{p}}=\frac{\mathrm{D}}{\mu_{0} \mu_{\mathrm{p}} \mathrm{e}^{2}} \\
& \Re_{\mathrm{gx}} \| \Re_{\mathrm{gz}}=\frac{\Re_{\mathrm{gx}} \Re_{\mathrm{g} z}}{\Re_{\mathrm{gx}}+\Re_{\mathrm{gz}}} \\
& \Re_{\mathrm{gx}}=\frac{\delta}{\mu_{0} \mathrm{e}^{2}}, \quad \Re_{\mathrm{gz}}=\frac{2 \delta}{\mu_{0}(\mathrm{D}-\delta)(\mathrm{e}-\delta)}+\frac{\mathrm{D}}{\mu_{0} \mu_{\mathrm{p}} \mathrm{e}(\mathrm{e}-\delta)}
\end{aligned}
$$

ここでは, 単位セルと接する上下の粒子の厚さを $\mathrm{e} / 2$ として いる. $\mu_{\mathrm{p}}$ は粒子固有の比透磁率である. 磁束密度 $\mathrm{B}$ と磁化 $\mathrm{M}$ の関係は磁化率 $\chi$ を用いて表すことができる.

$$
\mathrm{B}=\mu_{0}(1+\chi) \mathrm{H}=\mu_{0} \mathrm{H}+\mathrm{M}
$$

磁化が飽和したときの磁束密度を飽和磁束密度Bs とすると, そのときの飽和磁界Hsは相対密度RDを用いて表すことがで きる.

$$
\mathrm{Hs}=\frac{\mathrm{Bs} \cdot \mathrm{RD}}{\mu_{0} \mu_{\mathrm{ue}}}, \mathrm{RD}=\frac{\mathrm{De}^{2}}{(\mathrm{D}+\delta)(\mathrm{e}+\delta)^{2}}
$$

\section{2 .2 粒子径が分布を有する場合}

粒子径が分布を有する場合における圧粉磁心の比透磁率を 求める.これまで粒子は一定の粒子径Dとして取り扱ったが, 粒子径は分布を持っているので粒子に番号 $\mathrm{j}$ をりその粒子径 を $\mathrm{D}_{\mathrm{j}}$ とする. 単位セルの比透磁率 $\mu_{\mathrm{ue}}\left(\delta, \mathrm{e}_{\mathrm{j}}, \mathrm{D}_{\mathrm{j}}\right)$ から粒子径 $\mathrm{D}_{\mathrm{j}}$ からなる圧粉磁心の比透磁率 $\mu_{\mathrm{je}}\left(\delta, \mathrm{e}_{\mathrm{j}}, \mathrm{D}_{\mathrm{j}}\right)$ を計算する. Fig.13 は粒子径 $\mathrm{D}_{\mathrm{j}}$ を持つ圧粉磁心のモデルを示す.

磁気抵抗 $\Re_{\mathrm{u}}$ を有する単位セル (幅 $\mathrm{e}_{3}$, 高さ $\mathrm{e}_{2}$, 長さ $\mathrm{e}_{1}$ ) $\mathrm{N}_{\mathrm{j}}$ 個 により幅 $\mathrm{w}_{\mathrm{j}}$, 高さ $\mathrm{E}$, 長さ $\mathrm{L}$ のブロックを形成し， $\mathrm{L} / \mathrm{e}_{1}$ 個の 直列回路 (磁気抵抗を $\Re_{\mathrm{jn}}$ とする) と $\left(\mathrm{E} / \mathrm{e}_{2}\right) \times\left(\mathrm{w}_{1} / \mathrm{e}_{3}\right)$ 個の並 列回路からなるとする. そのブロックの磁気抵抗を $\Re$, とし $\tau$, 比透磁率 $\mu_{\mathrm{rc}}$ は単位セルのそれ $\mu_{\mathrm{ue}}$ を用い次式で表すこと ができる.

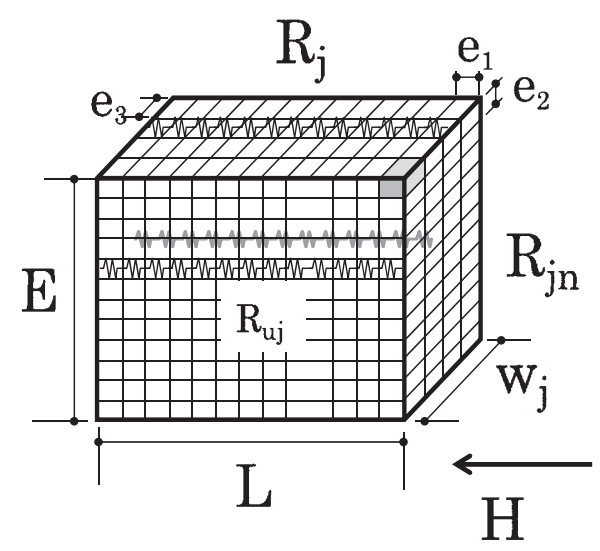

Fig.13 Stacking model of the unit cells. 
$L E w_{j}=N_{j} e_{1} e_{2} e_{3}$

直列回路: $\Re_{\mathrm{jn}}=\frac{\mathrm{L}}{\mathrm{e}_{1}} \Re_{\mathrm{uj}}$

並列回路: $\frac{1}{\Re_{\mathrm{j}}}=\frac{\mathrm{Ew}_{\mathrm{j}}}{\mathrm{e}_{2} \mathrm{e}_{3}} \times \frac{1}{\Re_{\mathrm{jn}}}$

$\mu_{\text {je }}\left(\delta, \mathrm{e}_{\mathrm{j}}, \mathrm{D}_{\mathrm{j}}\right)=\mu_{\text {uje }}\left(\delta, \mathrm{e}_{\mathrm{j}}, \mathrm{D}_{\mathrm{j}}\right)$

次に, 粒子径分布をもつ場合について圧粉磁心の比透磁率 $\mu_{\mathrm{me}}(\delta)$ を求める. Fig.14 はそのモデルを示す．圧粉磁心は幅 $\mathrm{W}$, 高さ E, 長さ L を有し, 各粒子径 $\mathrm{D}_{\mathrm{j}}$ からなる比透磁率 $\mu_{\mathrm{je}}$ を持つ並列回路からなると仮定する.さらに，圧粉磁心は反 磁界を生じない構造を有するものとし, 磁界方向の長さLは, 無限大あるいは閉磁路における磁路長を意味する.閉磁路の 場合，内径と外径は同一であると近似した。

その場合磁気抵抗は次式で表すことができる.

$$
\frac{1}{\Re}=\frac{\left(\mu_{0} \mu_{\mathrm{me}} \mathrm{WE}\right)}{\mathrm{L}}=\sum_{\mathrm{j}} \frac{1}{\Re_{\mathrm{j}}}=\left(\sum_{\mathrm{j}} \frac{\left(\mu_{0} \mu_{\mathrm{je}} \mathrm{W}_{\mathrm{j}} \mathrm{E}\right)}{\mathrm{L}}\right)
$$

この結果, 比透磁率 $\mu_{\mathrm{me}}(\delta)$ は

$$
\begin{aligned}
& \mu_{\text {me }}(\delta)=\sum_{j} \frac{\mathrm{w}_{\mathrm{j}}}{\mathrm{W}} \mu_{\mathrm{je}}\left(\delta, \mathrm{e}_{\mathrm{j}}, \mathrm{D}_{\mathrm{j}}\right) \\
& =\sum_{\mathrm{j}} \mathrm{f}\left(\mathrm{D}_{\mathrm{j}}\right) \mu_{\mathrm{je}}\left(\delta, \mathrm{e}_{\mathrm{j}}, \mathrm{D}_{\mathrm{j}}\right)=\sum_{\mathrm{j}} \mathrm{f}\left(\mathrm{D}_{\mathrm{j}}\right) \mu_{\text {uеe }}\left(\delta, \mathrm{e}_{\mathrm{j}}, \mathrm{D}_{\mathrm{j}}\right) \\
& \sum_{\mathrm{j}} \mathrm{f}\left(\mathrm{D}_{\mathrm{j}}\right)=1
\end{aligned}
$$

となる，ここで， $\mathrm{w}_{\mathrm{j}} / \mathrm{W}$ は粒子径 $\mathrm{D}_{\mathrm{j}}$ の確率密度関数 $\mathrm{f}\left(\mathrm{D}_{\mathrm{j}}\right)$ に等 しい.

3.2 .3 粒子間ギャップ幅に分布を有する場合

粒子間ギャップ幅が分布を有する場合における圧粉磁心の 比透磁率 $\mu_{\mathrm{me}}$ を求める. ギャップ幅は分布を有するとし, $\mathrm{k}$ 番 目のギャップ幅を $\delta_{\mathrm{k}}$, 確率密度 $\mathrm{g}\left(\delta_{\mathrm{k}}\right)$, 比透磁率を $\mu_{\mathrm{kme}}\left(\delta_{\mathrm{k}}\right)$ と する.これを等価回路で考えると, 直列接続と並列接続が考 えられるが,ここでは簡略化するために並列接続のみを考え た。比透磁率 $\mu_{\mathrm{me}}$ は (8) 式と同様に下記式で求められる.

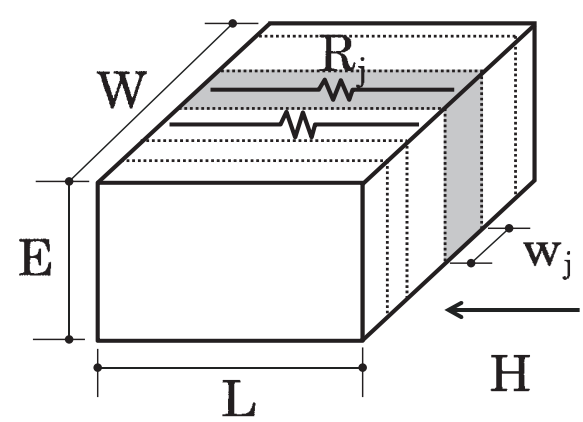

Fig.14 Blocking model of the blocks with each particle size.

$$
\begin{aligned}
& \mu_{\mathrm{me}}=\sum_{\mathrm{k}} \mathrm{g}\left(\delta_{\mathrm{k}}\right) \mu_{\mathrm{kme}}\left(\delta_{\mathrm{k}}\right) \quad \sum_{\mathrm{k}} \mathrm{g}\left(\delta_{\mathrm{k}}\right)=1 \\
& \mathbf{B}=\mu_{0} \mu_{\mathrm{me}}(\mathrm{H}<\mathrm{Hs}) \mathrm{H}
\end{aligned}
$$

$\mu_{\mathrm{me}}(\mathrm{H}<\mathrm{Hs})$ は, 各粒子径 $\mathrm{D}_{\mathrm{j}}$ について $\mathrm{Hs}$ 以上のHについては Bに寄与しないとして $\mu_{\mathrm{me}}$ を計算したことを意味する. 式(14) から, 各磁界における微分透磁率の実測值と計算值の相対誤 差が最小となるギャップ幅 $\delta$ と確率密度 $\mathrm{g}$ 求めた. これを, 実測した直流初磁化曲線から各Hに対してBとHの比から微 分透磁率を計算して得た直流重畳特性と比較し近似の妥当性 を評価した. 低磁界における微分透磁率の低下は, 強磁性体 の磁化過程モデルであるJiles-Athertonモデルにより説明され ている ${ }^{8)}$. そのモデルによると, 磁化過程は可逆的な磁壁移 動, 不可逆的な磁壁移動および回転磁化から構成されており, 低磁界における振る舞いは可逆的な磁壁移動によるものとさ れている. 本モデルにおいては, この効果は考慮しておらず, 低磁界での微分透磁率は一定とした。

3.3 NMGB モデルを計算するための粒子径の確率密度と磁気 定数

一般に，粒度分布は対数正規分布で近似できる．実測値の 累積粒度分布から, 最小二乗法により質量での幾何平均径 $\mathrm{D}_{\mathrm{gave}}$ と幾何標準偏差 $\sigma_{\mathrm{g}}$ を求め, 粒子径の確率密度を計算し た. 飽和磁束密度 $B_{s}$ は, 振動試料型磁力計 (VSM: Vibrating Sample Magnetometer)による粉末磁化の測定から求めた. 純 鉄粉については, 磁界 $1.19 \mathrm{M} \mathrm{A} / \mathrm{m}$ において単位質量あたりの 磁化 $213 \mathrm{emu} / \mathrm{g}$ から飽和磁束密度 $\mathrm{B}_{\mathrm{s}}$ として $2.10 \mathrm{~T}$ を得た. Fe6.5 mass \% Si 粉末については, 磁界 $1.19 \mathrm{M} \mathrm{A} / \mathrm{m}$ での単位質量 あたりの磁化 $191 \mathrm{emu} / \mathrm{g}$ から飽和磁束密度 $\mathrm{B}_{\mathrm{s}}$ として $1.80 \mathrm{~T}$ を 得た. 粒子固有の比透磁率 $\mu_{\mathrm{p}}$ は, 純鉄粉については文献值 ${ }^{9}$ からバルクの值を用い 1500 とした. Fe-6.5 mass\%Si粉末につ いては, 傾斜型 $\mathrm{Fe}-6.5$ mass \% Si である電磁鋼板の值 4100 を 用いた ${ }^{1)}$.アスペクト比 $\mathrm{p}$ は実測值 Fig.5を適用した．粒度分 布の粒子径は, 直径eを持つ球としてのデータであるため, モ デルでは一辺 $e^{\prime}, e^{\prime}, p e$ 'を持つ直方体として下記式により e'を 計算して用いた.

$$
\mathrm{e}^{\prime}=(\pi / 6 \mathrm{p})^{1 / 3} \times \mathrm{e}
$$

3.4 NMGB モデルによる直流重畳特性近似

Fig.15は純鉄粉について，水アトマイズ粉末の各球形化条 件およびガスアトマイズ粉末における微分透磁率の測定值と 計算結果を示すＦig.16は，各磁界における微分透磁率の相 対誤差を示す. 計算においては, ギャップ幅に分布を持たせ たモデルによる式(13) を用いた. Table 2 はその結果を示す. ギャップ幅分布においては，相対誤差が最小となるように ギャップ数kとして4 6を用いた. ギャップ幅分布について, 対数正規分布に従うと仮定して幾何平均値・幾何標準偏差を 計算した ${ }^{5)}$. 水アトマイズ粉において, aから d と球形化する ことによりギャップ幅の幾何平均值は0.61 $\mu \mathrm{m}$ から0.66 $\mu \mathrm{m}$ と わずかに大きくなり, 幾何標準偏差は $1.77 \mu \mathrm{m}$ から $1.62 \mu \mathrm{m}$ と 


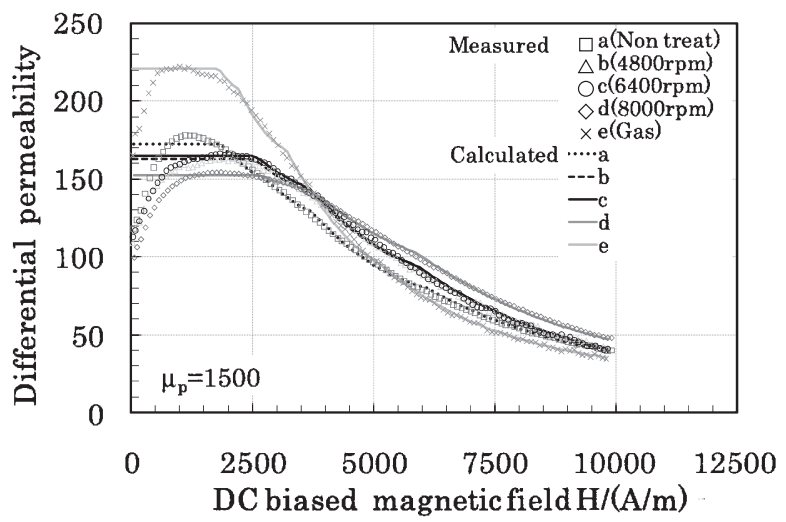

Fig.15 Measured and calculated DC biased magnetic property of the cores made of iron powder $(a, b, c, d, e)$.

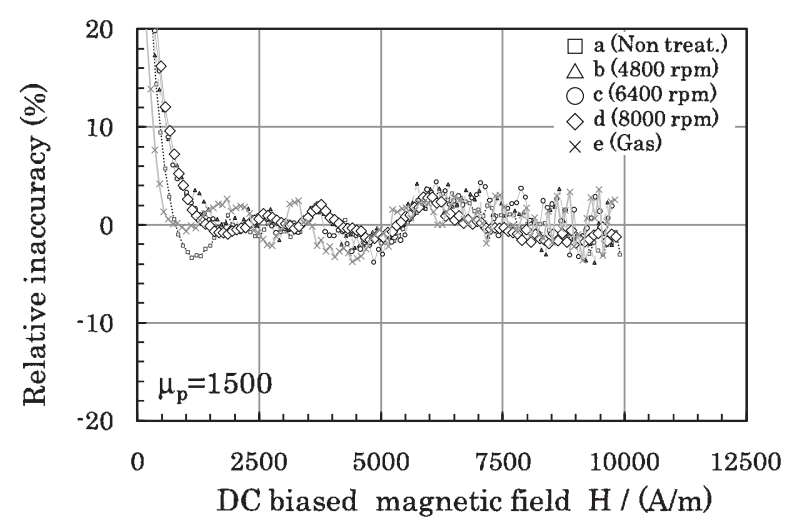

Fig.16 Relative inaccuracy between calculated and measured permeability of the cores made of iron powder $(a, b, c, d, e)$.

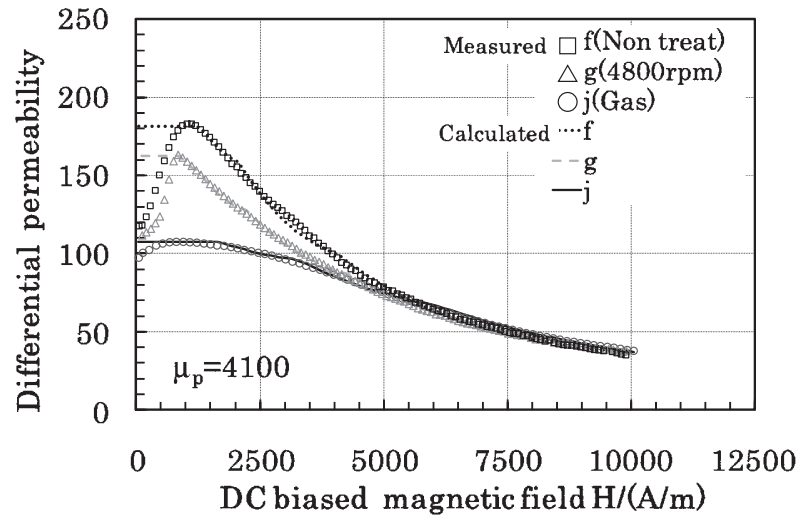

Fig.17 Measured and calculated DC biased magnetic property of the cores made of Fe- 6.5 mass $\%$ Si powder $(f, g, j)$.

小さくなった. また, 相対誤差もaでー3.34〜3.44\%, dで-1.95 〜 $2.80 \%$ と小さくなった. ガスアトマイズ粉末については, ギャップ幅幾何平均值, 幾何標準偏差とも最小となった.

Fig. 17 に Fe-6.5 mass\% Si 粉末について, 水アトマイズ粉末 の各球形化条件およびガスアトマイズ粉末における微分透磁 率の測定值と計算結果を示す. Fig.18は, 各磁界における微 分透磁率の相対誤差を示す.計算は純鉄粉と同様におこなっ た. Table 3 はその結果を示す. ギャップ幅分布においては ギャップ数 $\mathrm{k}$ とて4 5を用いた. 水アトマイズ粉において, $\mathrm{f}$ ら $\mathrm{g}$ と球形化されるほどギャップ幅の平均值は $0.72 \mu \mathrm{m}$ から $0.87 \mu \mathrm{m}$ と大きくなり，標準偏差も $1.77 \mu \mathrm{m}$ から $1.92 \mu \mathrm{m}$ と大 きくなった. また, 相対誤差はfで-4.68〜 4.37\%, gで-2.73 〜 3.20\% と小さくなった. ガスアトマイズ粉末については, ギャップ幅幾何平均値, 幾何標準偏差とも最大となった.

Table 2 Calculated gap width distribution and inaccuracy of differential permeability on the cores made of iron powder.

\begin{tabular}{|c|c|c|c|c|c|c|c|c|c|c|}
\hline Rotation & \multirow{2}{*}{\multicolumn{2}{|c|}{$\begin{array}{r}\text { a (Non treat.) } \\
\text { Probabilit } \\
\text { Width } / \mu \mathrm{m} \quad \text { y density/ } \\
\% \\
\end{array}$}} & \multicolumn{2}{|c|}{$\begin{array}{r}\text { b (4800rpm) } \\
\text { Probabilit }\end{array}$} & \multicolumn{2}{|c|}{ c (6400rpm) } & \multicolumn{2}{|c|}{$\mathrm{d}(8000 \mathrm{rpm})$} & \multicolumn{2}{|c|}{$\begin{array}{r}\text { e (Gas atomization) } \\
\text { Probabilit }\end{array}$} \\
\hline Gap & & & Width $/ \mu \mathrm{m}$ & $\begin{array}{c}\text { Probabilit } \\
\text { y density/ } \\
\%\end{array}$ & Width $/ \mu \mathrm{m}$ & $\begin{array}{c}\text { Probabilit } \\
\text { y density/ } \\
\%\end{array}$ & Width $/ \mu \mathrm{m}$ & $\begin{array}{c}\text { Probabilit } \\
\text { y density/ } \\
\%\end{array}$ & Width $/ \mu \mathrm{m}$ & $\begin{array}{c}\text { Probabilit } \\
\text { y densityl } \\
\%\end{array}$ \\
\hline \multirow{6}{*}{ 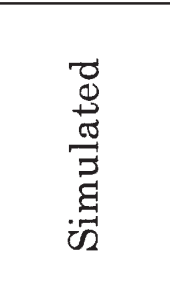 } & & 46.1 & & 42.0 & & 40.5 & & 42.8 & & 40.5 \\
\hline & & & & & 0.4 & & & & & \\
\hline & 184 & 17.1 & 0.200 & 19.0 & 0.210 & 20.0 & 0.230 & 18.0 & 0.170 & 25.0 \\
\hline & 78 & 5.8 & 0.080 & 5.0 & 0.090 & 5.5 & 0.110 & 3.2 & 0.065 & 7.5 \\
\hline & 025 & 2.0 & & & & & & & 0.025 & 2.0 \\
\hline & 006 & 1.0 & & & & & & & & \\
\hline $\begin{array}{l}\text { Average } \\
\text { gap width }\end{array}$ & \multicolumn{2}{|c|}{$0.61(※ ※ 0.58)$} & \multicolumn{2}{|c|}{0.64} & \multicolumn{2}{|c|}{$0.64(0.65)$} & \multicolumn{2}{|c|}{$0.66(0.68)$} & \multicolumn{2}{|c|}{$0.46(0.47)$} \\
\hline $\begin{array}{l}\text { Standard } \\
\text { deviation }\end{array}$ & \multicolumn{2}{|c|}{$1.77(2.38)$} & \multicolumn{2}{|c|}{1.67} & \multicolumn{2}{|c|}{$1.66(1.72)$} & \multicolumn{2}{|c|}{$1.62(2.85)$} & \multicolumn{2}{|c|}{$1.57(1.60)$} \\
\hline ※\%) & .34 & 3.44 & -3.82 & 4.23 & -3.85 & 4.30 & -1.95 & 2.80 & -3.78 & 3.65 \\
\hline data(k A & 0.57 & 9.91 & 0.91 & 9.74 & 0.82 & 9.75 & 0.93 & 9.83 & 0.45 & 9.80 \\
\hline
\end{tabular}

※: Inaccurancy between mesured and calculated differentil permebility, $※:$ Measured value 


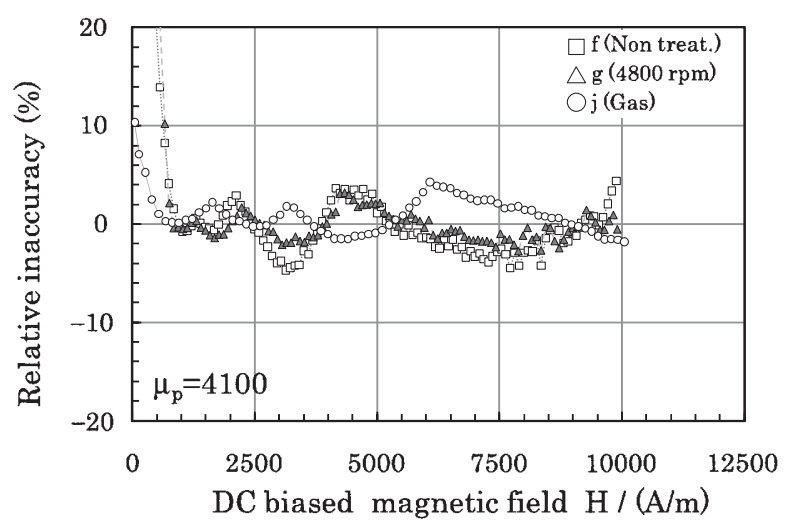

Fig.18 Relative inaccuracy between calculated and measured permeability of the cores made of $\mathrm{Fe}-6.5$ mass $\% \mathrm{Si}$ powder $(f, g, j)$.

上記 2 種類の粉末において, 球形化することによりギャッ プ幅の幾何平均值が大きくなる.一方, 幾何標準偏差は純鉄 粉では小さくなり, $\mathrm{Fe}-6.5 \mathrm{mass} \% \mathrm{Si}$ 粉末では大きくなった. この原因は, Table 1からわかるように成形密度の違いが考え られる. 前者では, 球形化するに従い成形密度が大きくなり 空隙が少なることにより幾何標準偏差が小さくなったと考え られる. 幾何平均值は $0.61 \mu \mathrm{m}$ から $0.66 \mu \mathrm{m}$ とほぼ変化してい ないので, 成形密度が大きくなった効果は, 空隙の減少にの み寄与したものと考えられる. 一方, 後者では, 球形化する に従い成形密度が小さくなり, 空間ができることにより
Table 3 Calculated gap width distribution and inaccuracy of differential permeability on the cores made of Fe- 6.5 mass $\%$ Si powder.

\begin{tabular}{|c|c|c|c|c|c|c|}
\hline \multirow{2}{*}{$\begin{array}{c}\text { Rotation } \\
\text { Gap }\end{array}$} & \multirow{2}{*}{\multicolumn{2}{|c|}{$\begin{array}{l}\mathrm{f} \text { (Non treat.) } \\
\text { Width } / \mu \mathrm{m} \begin{array}{l}\text { Probabilit } \\
\text { y density/ }\end{array}\end{array}$}} & \multirow{2}{*}{\multicolumn{2}{|c|}{$\begin{array}{cc}\mathrm{g}(4800 \mathrm{rpm}) \\
\text { Width } / \mu \mathrm{m} & \begin{array}{c}\text { Probabilit } \\
\mathrm{y} \text { density/ }\end{array}\end{array}$}} & \multirow{2}{*}{\multicolumn{2}{|c|}{\begin{tabular}{|cc}
$\mathrm{j}$ (Gas atomization) \\
\\
Width $/ \mu \mathrm{m}$ & $\begin{array}{l}\text { Probabilit } \\
\text { y density/ }\end{array}$
\end{tabular}}} \\
\hline & & & & & & \\
\hline \multirow{5}{*}{ 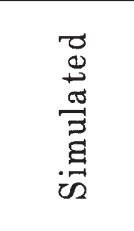 } & 1.640 & 52.0 & 1.800 & 58.4 & 2.530 & 54.3 \\
\hline & 0.450 & 29.0 & 0.490 & 25.0 & 0.720 & 28.0 \\
\hline & 0.185 & 15.0 & 0.210 & 12.0 & 0.350 & 15.0 \\
\hline & 0.080 & 4.0 & 0.085 & 3.5 & 0.150 & 2.7 \\
\hline & & & 0.037 & 1.1 & & \\
\hline $\begin{array}{l}\text { Average gap } \\
\text { width }\end{array}$ & \multirow{2}{*}{\multicolumn{2}{|c|}{$\begin{array}{c}0.72(※ ※ 0.42) \\
1.77(2.25)\end{array}$}} & \multirow{2}{*}{\multicolumn{2}{|c|}{$\begin{array}{l}0.87(0.62) \\
1.95(2.76)\end{array}$}} & \multirow{2}{*}{\multicolumn{2}{|c|}{$\begin{array}{l}1.23(0.69) \\
2.17(2.44)\end{array}$}} \\
\hline $\begin{array}{l}\text { Standard } \\
\text { deviation }\end{array}$ & & & & & & \\
\hline ※) & -4.68 & 4.37 & -2.73 & 3.20 & -1.61 & 4.27 \\
\hline $\mathrm{Hdata}(\mathrm{k} \mathrm{A} / \mathrm{m})$ & 0.66 & 9.89 & 0.66 & 9.91 & 0.26 & 9.92 \\
\hline
\end{tabular}

※ : Inaccurancy between mesured and calculated differentil permebility, ※: Measured value

ギャップ幅の分布が大きくなることが考えられる.この組成に よる違いは, ビッカース硬度は前者では約 50 後者では約 350 とおおきくなることによる成形性の違いによるものと考えら れる ${ }^{10)}$.

3.5 NMGB モデルによるギャプ幅分布

Table 2,3においてモデルから推定されたギャップ幅分布に ついて，実測値との比較による検証をおこなつた. Fig19, 20

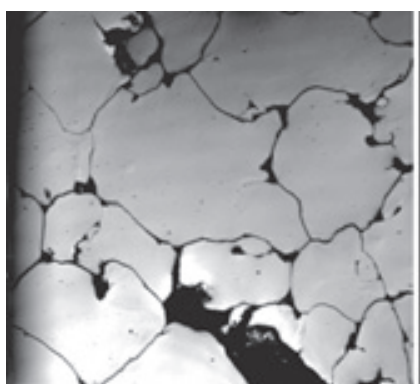

(a)

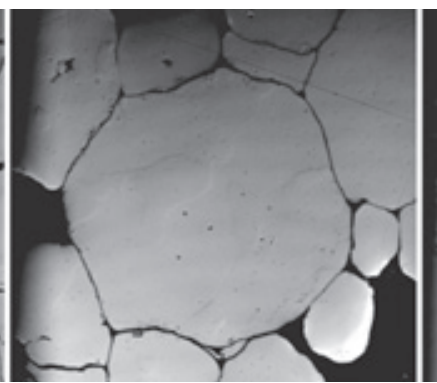

(c)

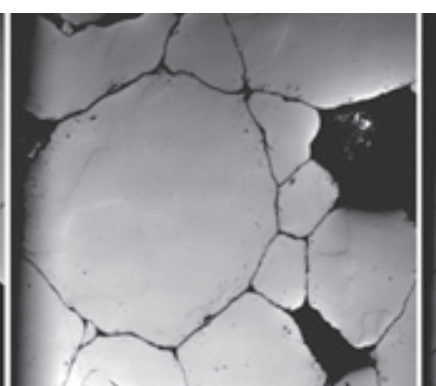

(d)

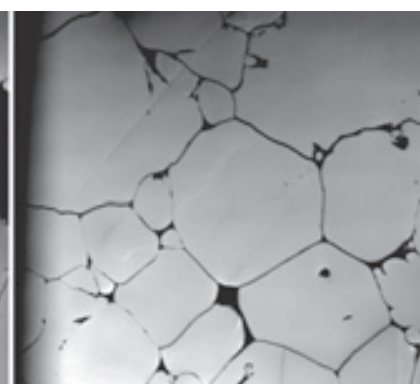

(e) $25 \mu \mathrm{m}$

Fig.19 Cross sectional SEM photographs of the cores made of iron powder (a, b, c, d, e).

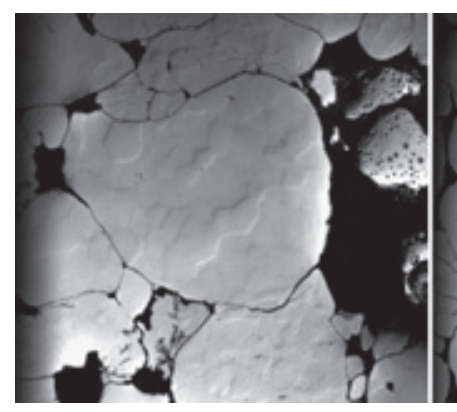

(f)

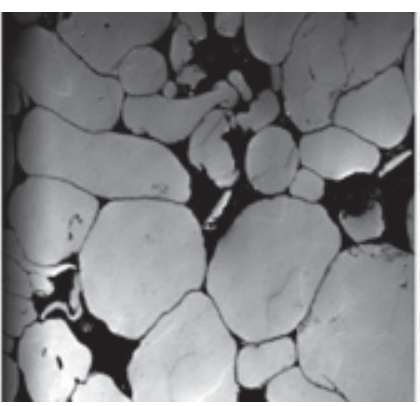

(g)

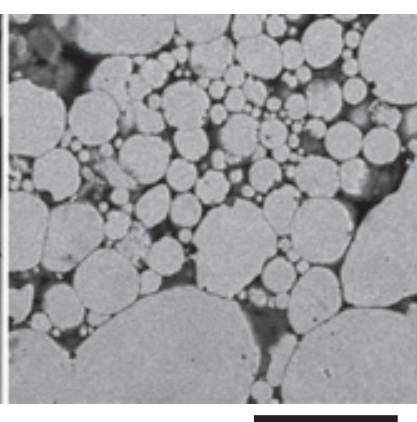

(j) $25 \mu \mathrm{m}$

Fig.20 Cross sectional SEM photographs of the cores made of Fe-6.5 mass \% Si powder (f, g, e). 
は純鉄粉による試料 $\mathrm{a} \sim \mathrm{e}, \mathrm{Fe}-6.5$ mass \% Si 粉末による試料 $\mathrm{f} \sim \mathrm{j}$ にいての断面研磨写真を示す.この写真において, 縱・ 横を $20 \mu \mathrm{m}$ 間隔に区切り $60 \times 60 \mu \mathrm{m}^{2}$ の領域において, 区切り 線と交差するギャップ幅を測定した．測定においては，研磿 において, 粒子の脱落によると考えられる大きなギャップに ついては除外した．実測值は計算値と同様に，対数正規分布 に従うと仮定して幾何平均値と幾何標準偏差を計算した。 Table 2,3においてその結果を示した. 幾何平均值と幾何標準 偏差值を Average gap width とStandard deviationの括弧で示し た. Fig.21は, 各粉末における球形化条件とギャプ幅幾何平均 值の計算値と測定結果を示す.誤差は純鉄粉の場合, a: $5.17 \%$, c: $-1.54 \%, \mathrm{~d}:-2.94 \%, \mathrm{e}:-2.12 \%$ と $5.17 \%$ 以下であった. Fe6.5 mass $\%$ Si 粉末の場合は, f: $71.4 \%, \mathrm{~g}: 40.3 \%, \mathrm{j}: 78.3 \%$ と大 きかった. 幾何標準偏差が2.25 2.76 $\mu \mathrm{m}$ であることを考慮す ると, ばらつきが大きい。すなわち, 今回の測定条件である 縦・横を $20 \mu \mathrm{m}$ 間隔に区切り $60 \times 60 \mu \mathrm{m}^{2}$ の領域における測定 では粗すぎる可能性がある。

\section{4 ま とめ}

水アトマイズ粉を表面改質装置により球形化処理を行い, 直流重畳特性への影響を検討した. また，ガスアトマイズ粉 も評価した.これらの試料について直流重畳特性を測定し, これにNMGB モデルを適用し計算値と実測値の比較を行な い, モデルの妥当性を評価した。このモデルより得られた ギャップ幅分布を実測值と比較した.

水アトマイズによる純鉄粉を球形化することによりアスペ クト比の改善が可能であり, $8000 \mathrm{rpm} 180 \mathrm{sec}$ の処理において

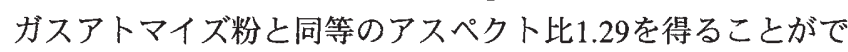
きた. 球形化を行なうことにより直流重畳特性の改善がはか れた.これらの試料にNMGBモデルを適用し, 各磁界におけ る微分透磁率の相対誤差 $\pm 4.23 \%$ 以下を得た。

水アトマイズによる $\mathrm{Fe}-6.5 \mathrm{mass} \% \mathrm{Si}$ 粉末を球形化すること によりアスペクト比の改善が可能であることが確認できたが, 直流重畳特性の改善ははかれなかった。これらの試料に NMGB モデルを適用し相対誤差 $\pm 4.68 \%$ 以下得た.このモデ ルから得られたギャップ幅分布を実測值と比較した. 純鉄粉 末では誤差は $5.17 \%$ 以下となった. Fe-6.5 mass\% Si粉末では, $78.3 \%$ 以下となったが, 幾何標準偏差值が $2.25 \sim 2.76 \mu \mathrm{m}$ とば らつきが大きいことが原因であると考えられる.

この結果より，このモデルはギャップ幅に分布を仮定する ことにより, 直流重畳特性におよぼす物理的要因との相関が 容易になると考えられる.

\section{文献}

1) M. Misao, H. Ninomiya, and T. Yamaji: "High Silicon Steel

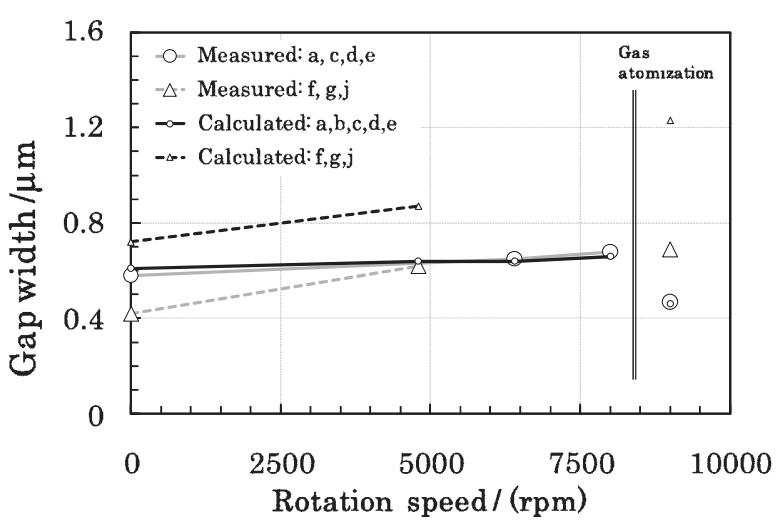

Fig.21 Rotation speed dependency of measured and calculated gap width.

Sheets Realizing Excellent High Frequency Reactor Performance", JFE Technical Report, No. 6, (2005) 12-17.

2) T. Maeda, H. Toyoda, et al.: "Development of Low-Iron-Loss Sintered Magnetic Material", SEI Technical Review, No. 166, (2005) 1-6.

3) T. Saito and S. Takemoto: "Effects of Density and Particle Shape on the Permeability of Fe-Si-Al Compressed Core", J. Jpn. Soc. Powder Powder Metallurgy, 52(2005)571-575.

4) N. Shimatani and H. Fujita: "Approximation of magnetization curves by Exponential Series", The Transactions of the Institute of Electrical Engineers of Japan, A101 (1981)463-470.

5) T. Saito, Y. Fujita, and S. Takemoto: "Initial Magnetization Curves for Powder Cores Taking into Account Distribution of Demagnetizing Field", J. Magn. Soc. Jpn., 33(2009)434440.

6) F. Mazaleyrat, V. Valerie, et al.: "Permeability of Soft Magnetic Composites From Flakes of Nanocrystalline Ribbon", IEEE Transactions on Magnetics, 38(2002)3132-3134.

7) H. Hamakake, K. Kageyama, et al.: "Magnetic Properties of Dust Cores Made of Nanocrystalline FeSiCuNbCrB Powders", Advanced in Powder Metallurgy \& Particulate Materials., 3(10) (2004) 179-193.

8) D.C. Jiles and D.L. Atherton: "Theory of Ferromagnetic Hysteresis", J. Magn. \& Magn. Mater., 61(1986)48-46.

9) T. Kato and T. Tomioka: "On the Free-Cutting Magnetic Pure Iron", Electric Furnace Steel, 38(1967)2-8.

10) K. Arai, T. Takeuchi, et al.: "Effect of Quenching on OrderDisorder Phase Transformation and Magnetic Anisotropy in High Silicon Iron Alloys", Grant-in-Aid for Scientific Research (A), (1987-1988)8. 